volume. All the papers, however, draw their connexions to Cole's work in perfectly natural ways, including in many cases descriptions of the way Cole had suggested or influenced the work. One obtains therefore an unusual view of the way in which one man has contributed directly or indirectly to the development of the field. The result is a fitting tribute to Cole, quite apart from being a valuable collection of papers on membrane biophysics.

D. Noble

\section{Heredity for Laymen}

Heredity in Humans. By Amram Scheinfeld. Pp. xvi+303. (Chatto and Windus: London, January 1973.) £2.50.

THIS is the fifth, or, according to one's classification, the ninth book by Scheinfeld aimed at explaining heredity to the layman, which began in 1939 with the publication of the very successful You and Heredity. It is not intended to compete with the more voluminous and detailed Your Heredity and Environment of 1965 , but may be regarded as an up-to-date successor to The Human Heredity Handbook published in 1956.

The approach is "pragmatic" rather than analytical or technical, attempting to answer many questions asked by laymen in laymen's language: for instance why children resemble their parents, but not always; in what way men and women "naturally" differ; how certain diseases and defects are inherited; how ethnic groups differ in their genes; what part heredity plays in intelligence, talent, behaviour, personality and sex life.

Most offered explanations are roughly correct, but the method of presentation is often unnecessarily crude and also too dogmatic. It is probably not very useful to describe dominant genes as "bully genes", genes producing various oddities as "freak genes", genes working unexpectedly and only under some circumstances as "temperamental genes"--genes of late onset as "Rip van Winkle genes". Some curious concepts also should be pointed out. Why, for instance, call some Indians, Arabs and North Africans "dark skinned whites"?

The situations used for the illustration of the author's points of view in respect of race, intelligence differences and similar problems are mostly chosen from the orbit of metropolitan New York and sometimes a certain bias seems to have prevailed; it is, for instance, curious not to mention the Germans among the people who contributed to music. Nevertheless, if laymen do not take the text as gospelwhich, unfortunately, some of them tend to do-this book can do a good deal in counteracting antiquated and bigoted assertions.

\title{
Common Toad
}

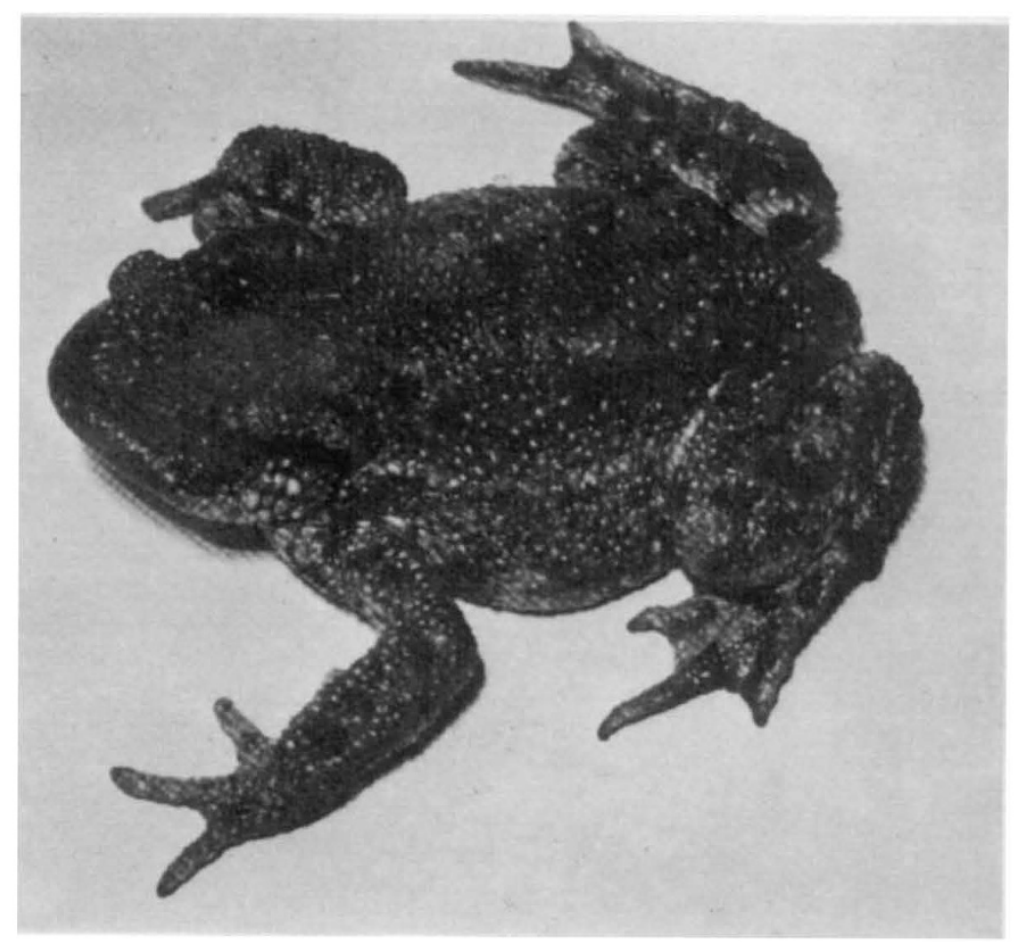

A particularly large female toad illustrating the adaption of amphibians to relatively dry environments in Amphibians, by J. F. D. Frazer (Wykeham Publications, London, 1973).

\section{Diseases of Plants}

The Principles of Plant Pathology. By S. A. J. Tarr. Pp. 632. (Macmillan: London and Basingstoke, September 1972.) $£ 10.00$.

PLANT pathology, whether interpreted narrowly or as broadly as in this book, is to plants what the whole of medicine and veterinary science is to man and animals. It is therefore not surprising that Butler and Jones's monumental textbook Plant Pathology of 1949 is said to have marked the end of an era. Increasingly the subject requires several multi-author-volumes. The facts about individual pathogens, diseases and ways to control them seem best presented in loose pamphlets sold on a subscription basis, as some are through the Commonwealth Mycological Institute. In this way every topic can have specialist treatment and be revised separately whenever necessary. Review journals satisfy a further part of the need, but neither pamphlet nor review would provide the "thorough background to all aspects of plant pathology" which this book is claimed to do. The task was certainly ambitious because, with only a brief history of plant pathology written by $\mathrm{Dr}$ Ainsworth and several helpers who checked other chapters, Dr Tarr undertook work that recently occupied three volumes of contributions by many authors. Struggling no doubt against severe limitations of space and price the author has produced an upto-date book of pleasing format, with few errors but with illustrations that are rather scanty and often disappointingly presented.

Many apologies for brief accounts show that Dr Tarr knew how much he was omitting. Estimates of the soundness of his choice will probably differ depending on the interests and experience of his readers. So will opinions of the wisdom of mentioning rodents, birds and molluscs as if they, as well as some angiosperms and chemical excesses or deficiencies, should be regarded as plant pathogens. However, here as elsewhere, Dr Tarr plainly states the alternatives possible and the consequences that each may incur. $\mathrm{He}$ rarely obscures our ignorance under a heap of terminology, but occasionally invents terms for which the need is doubtful. Dr Tarr states that he has aimed his book at students, and novices will appreciate the wide scope of the book and be glad of the reminders that come in the rather repetitious and overlapping early chapters, some so abbreviated that they contain little but lists and generalizations. Surely a treatment of the major nutrients (NPK) that only 